\title{
Effect of Cooking Time and Storage Temperature on the Quality of Home-Made Retort Pouch Packed Chuncheon Dakgalbi
}

\author{
Muhlisin, Dong Soo Kim, Yeong Rae Song, Young Jae Cho', Cheon-Jei Kim², Byoung-Ki An², \\ Chang-Won Kang ${ }^{4}$, and Sung Ki Lee* \\ Department of Animal Products and Food Science, Kangwon National University, Chuncheon 200-701, Korea \\ ${ }^{I}$ College of Veterinary Medicine and Institute of Veterinary Science, \\ Kangwon National University, Chuncheon 200-701, Korea \\ ${ }^{2}$ Department of Food Science and Biotechnology of Animal Resources, Konkuk University, Seoul 143-701, Korea \\ ${ }^{3}$ College of Animal Bioscience and Technology, Konkuk University, Seoul 143-701, Korea \\ ${ }^{4}$ Department of Animal Science and Environment, Konkuk University, Seoul 143-701, Korea
}

\begin{abstract}
The aim of this research is to evaluate the effects of cooking time and storage temperature on the quality of home-made retort pouch packed Chuncheon Dakgalbi. The leg meat of broiler is being cut into cubes and is mixed with the Dakgalbi sauce and vegetables. Around $200 \mathrm{~g}$ of Chuncheon Dakgalbi is being stuffed into a retort pouch and then vacuumed. The retort pouch packed Chuncheon Dakgalbi is subjected to cooking (autoclaving) at $110^{\circ} \mathrm{C}$ and $0.75 \mathrm{Kgf}$ for 10,20 or $30 \mathrm{~min}$ and then transferred to the chilling room at $2^{\circ} \mathrm{C}$ for rapid cooling procedures. Subsequently, the samples are stored at $4^{\circ} \mathrm{C}$ or $25^{\circ} \mathrm{C}$ for $4 \mathrm{wk}$. According to results of sensory evaluation, the highest sensory scores were found in Chuncheon Dakgalbi which was cooked for $30 \mathrm{~min}(p<0.05)$. Prolonged cooking time tends to decrease the $\mathrm{pH}, \mathrm{CIE} \mathrm{L}^{*}$ and CIE a* levels, and slightly promote the lipid oxidation and protein deterioration. The Chuncheon Dakgalbi being cooked for 10 min promoted the lipid oxidation and protein deterioration during storage at $25^{\circ} \mathrm{C}$. Moreover, the total aerobic and anaerobic bacteria in Chuncheon Dakgalbi being cooked for 10 min started to grow after 3 wk of storage at $25^{\circ} \mathrm{C}$. Cooking (autoclaving) at $110^{\circ} \mathrm{C}$ for $30 \mathrm{~min}$ is able to maintain the quality and shelf-life of retort pouch packed Chuncheon Dakgalbion the market.
\end{abstract}

Key words: Chuncheon Dakgalbi, cooking, retort packaging, storage temperature

\section{Introduction}

Chuncheon Dakgalbi is a popular Korean dish, which was originally a local cuisine in Chuncheon city, Kangwon province, but recently became a traditional Korean food. In general, Chuncheon Dakgalbi is made by grilling chicken meat, sauce and vegetables including cabbage, sweet potato, and other ingredients. Dakgalbi are usually served in family restaurants or are sold in supermarkets as ready to cook Dakgalbi. As the fast economic development of Korea, people tended to be more mobile and have less time to prepare food. In recent years, food industries are developing convenience food including ready to cook and ready to eat products to meet the life style of customers (Jang and Lee, 2012). Moreover, the ready to eat

*Corresponding author: Sung Ki Lee, Department of Animal Products and Food Science, Kangwon National University, Chuncheon 200-701, Korea. Tel: 82-33-250-8646, Fax: 82-33251-7719, E-mail: skilee@kangwon.ac.kr products commonly have relatively long shelf-life so that products are more convenient to be transported to other country as the export commodities than fresh or ready to cook products.

Thermal processing can eliminate pathogenic microorganisms and enzymes for food preservation (Byun and Whiteside, 2007). One of the thermal processing model is retort processing which is described as the procedure that are used to heat containers (retort pouch in instance) in steam chamber (Trevino, 2009). The retortable pouch has re-emerged as a packaging alternative for convenience product and retort packs with thin-profile layers was developed to promote rapid heating and minimize the impact of heat on quality attributes (Awuah et al., 2007). Mohan et al. (2006) mentioned that the advantages of retort pouches are shelf stability, lower weight and storage space, relatively easy in preparation, and reduced heat exposure resulting in improved quality. Mostly, retort pouch are consisted of a four-ply laminate of polyester outside layer, aluminum foil, and cast polypropylene inner 
layer (Griffin, 1987). The advantage of retort pouch pack in comparison with other thermal processing pack is the shorter cooking time because of its high ration of surface area to volume, so that it has better taste, improved nutritional value and less moisture loss (Trevino, 2009). Retort packaging was commonly used for packaging of various kinds of seafood products, such as sardines (Ali et al., 2005), tuna (Ali et al., 2006), fowl meat (Lyon and Klose, 1981), shrimp (Mohan et al., 2006) but there is only few study on meat products, for instance vegetables with bacon (Heidelbaugh and Karel, 1970) and beef stew (Cremer and Pizzimenti, 1992).

Even though there are some traditional Korean foods that have been marketing in form of convenience food (ready to eat), the production and study of ready to eat Chuncheon Dakgalbi are still limited. A research to study the ready to eat Chuncheon Dakgalbi is needed. The presence study was conducted to examine the possibility of autoclaving at $110^{\circ} \mathrm{C}$ as the simple cooking method for home-made retort pouch packed Chuncheon Dakgalbi that will provide basic information which can be used for further study. This research also was conducted to study the effect storage temperature on the quality of homemade retort pouch packed Chuncheon Dakgalbi.

\section{Materials and Methods}

\section{Chicken}

The broilers (Cornish breed; 1,200 g; 4 wk) were slaughtered at Jung Woo Food Co., Ltd., (Korea). The carcasses were stored in a refrigerator at $5^{\circ} \mathrm{C}$ overnight and deboned at the next day ( $24 \mathrm{~h}$ after slaughter). The deboned chicken legs were vacuum-packed and transported to laboratory.

\section{Chuncheon Dakgalbi preparation}

The skin of the leg was removed and the meat was cut into a cube shape on the size of approximately $2 \times 2 \times 1 \mathrm{~cm}$. Other ingredients including cabbage, carrot, potato, and sweet potato, were cut also in uniform size. The cube meat was mixed with Dakgalbi sauce and other ingredients with composition of $50 \%$ of leg meat, $34 \%$ of Dakgalbi sauce, and $16 \%$ of vegetables including cabbage, carrot, potato and sweet potato. The ingredients of Dakgalbi sauce are presented in Table 1.

\section{Cooking and storage}

Two hundred g of Chuncheon Dakgalbi was weighed into a retort pouch pack $(19 \mathrm{~cm} \times 24 \mathrm{~cm}$; made with 12
Table 1. Chuncheon Dakgalbi sauce recipes

\begin{tabular}{cc}
\hline \hline Ingredients & Percent (\%) \\
\hline Soy sauce and pepper paste & 16.20 \\
Pepper etc. & 16.00 \\
Sugar etc. & 17.30 \\
Fresh garlic and onion & 28.90 \\
Other ingredients & 18.10 \\
Water & 3.50 \\
\hline Total & 100.00 \\
\hline
\end{tabular}

$\mu \mathrm{m}$ polyester as outer layer, $9 \mu \mathrm{m}$ aluminum foil, $15 \mu \mathrm{m}$ polyamides, $7 \mu \mathrm{m}$ aluminum foil, and $100 \mu \mathrm{m}$ cast polypropylene as inner layer) followed by vacuum packaging. The Chuncheon Dakgalbi was cooked in autoclave (Jeio Tech AC-13, Korea) at $110^{\circ} \mathrm{C}$ with pressure $0.75 \mathrm{Kgf} / \mathrm{cm}^{2}$. The initial temperature of chamber was $25^{\circ} \mathrm{C}$ and it took $30 \mathrm{~min}$ to reach the temperature of $110^{\circ} \mathrm{C}$ and pressure of $0.75 \mathrm{Kgf} / \mathrm{cm}^{2}$. The cooking times were 10,20 or $30 \mathrm{~min}$, started when the temperature reached $110^{\circ} \mathrm{C}$. Cooling and pressure releasing time of chamber was $20 \mathrm{~min}$. The cooked retort pouch packed Chuncheon Dakgalbi was transported to chilling room at $2^{\circ} \mathrm{C}$ for $5 \mathrm{~h}$ for cooling. The packs were stored at refrigerator temperature $\left(4^{\circ} \mathrm{C}\right)$ or room temperature $\left(25^{\circ} \mathrm{C}\right)$ for $4 \mathrm{wk}$. Total of six treatments was assigned from the combination of cooking times and storage conditions. Three retort packs of each treatment were opened at $0,1,2,3$, and $4 \mathrm{wk}$ of storage and then were ground for analysis. The proximate analysis and sen- sory evaluation were performed on $0 \mathrm{~d}$ of storage, chemical changes were measured on $0,1,2$, and $3 \mathrm{wk}$ and total aerobic and anaerobic bacteria were counted on $0,1,2,3$ and $4 \mathrm{wk}$.

\section{Proximate analysis and $\mathrm{pH}$ measurements}

The proximate analyses including moisture, crude protein, crude fat and crude ash were performed according to Association of Official Analytical Chemists (AOAC) methods (2000). For $\mathrm{pH}$ measurement, $10 \mathrm{~g}$ of sample was homogenized at 10,000 rpm for $60 \mathrm{~s}$ using a homogenizer (PH91, SMT Co. Ltd., Japan) with $100 \mathrm{~mL}$ of distilled water. The $\mathrm{pH}$ of sample slurry at room temperature was measured using a $\mathrm{pH}$ meter (SevenEasy $\mathrm{pH}$, MettlerToledo GmbH, Switzerland).

\section{Instrumental color}

The ground sample was placed on a petri dish and covered with a polyethylene plastic. The instrumental color including CIE L* (lightness), a* (redness), and b* (yellowness) was measured using a color difference meter (CR-400, Konica Minolta Sensing Inc., Japan). The color 
instrument was standardized with a white plate (Illuminant $\mathrm{C}$ : $\mathrm{Y}=93.6, \mathrm{x}=0.3134$, and $\mathrm{y}=0.3194)$. Ten times of random measurements were taken from each pack samples.

\section{Thiobarbituric acid reactive substances (TBARS) and volatile basic nitrogen (VBN)}

The TBARS value was measured according to Sinnhuber and Yu (1977). Briefly, $0.5 \mathrm{~g}$ of ground sample was mixed with 3 drops of antioxidant solution (3\% BHA$54 \%$ propylene glycol-3\% BHT-40\% Tween 20 ), $3 \mathrm{ml}$ of TBA solution (1\% 4,6-Dihydroxy-2-mercaptopyrimidine), and $17 \mathrm{ml}$ of $25 \%$ trichloroacetic acid. The mixture was heated at $100^{\circ} \mathrm{C}$ for $30 \mathrm{~min}$, and centrifuged at 3,500 rpm for $30 \mathrm{~min}$. An absorbance of supernatant was measured at $532 \mathrm{~nm}$ using a spectrophotometer (UV-mini-1240, Shimadzu, Japan). The results were calculated as mg malonaldehyde (MA) per $\mathrm{kg}$ sample. A total of four measurements were performed on each pack samples.

The analysis of volatile basic nitrogen (VBN) was measured according to the method of Kohsaka (1975). Five gram sample was homogenized with $30 \mathrm{ml}$ of $5 \%(\mathrm{w} / \mathrm{v})$ trichloroacetic acid using a homogenizer (Ultra-Turrax T25 basic, IkaWerke GmbH and Co., Germany) at 13,500 $\mathrm{rpm}$ for $2 \mathrm{~min}$. The homogenate was made up to $50 \mathrm{ml}$ of final volume with $5 \%(\mathrm{w} / \mathrm{v})$ TCA and filtered through a Whatman No. 1 filter paper. One milliliter of the filtrate and $1 \mathrm{ml}$ of borate buffer were placed in outer and inner of Conway dish, respectively, and then incubated at $37^{\circ} \mathrm{C}$ for $100 \mathrm{~min}$. Finally, the inner solution was titrated with $0.01 \mathrm{~N} \mathrm{HCl}$. A total of three measurements were performed on each pack samples.

\section{Total aerobic and anaerobic bacteria counts}

To determine the total aerobic and anaerobic bacteria counts, $10 \mathrm{~g}$ of sample was weighed and place in a sterile bag and homogenized with $90 \mathrm{ml}$ of $0.1 \%$ sterile peptone water for $2 \mathrm{~min}$ in a Stomacher 400 (Seward Co., UK). Serial dilutions were prepared using $0.1 \%$ sterile peptone water. One $\mathrm{ml}$ inoculums of appropriate dilution were spread on a plate count agar (PCA; Difco, USA). Plates were incubated at $35^{\circ} \mathrm{C}$ for $48 \mathrm{~h}$ on atmospheric condition for determination of total aerobic plate counts. The plates were incubated on an anaerobic jar equipped with gas pack anaerobe container system (Becton, Dickinson and Company, Ireland) for total anaerobic plate counts. After incubation, plates with 30-300 colonies were counted. Microbiological data were transformed into logarithms of the number of colony forming units $(\mathrm{Log} \mathrm{CFU} / \mathrm{g})$.

\section{Sensory evaluation}

Sensory evaluation of retort packed Chuncheon Dakgalbi was conducted by a panel consisting of 20 members. The panel was asked to evaluate the color, taste, texture, flavor and overall acceptability on a hedonic scale ( $9=$ very good, $7=$ good, $5=$ acceptable, $3=$ =poor, and $1=$ very poor). The retort pouch packed sample was served after heating on a microwave oven for $3 \mathrm{~min}$. The color, taste, flavor, and overall acceptability by sensory evaluation represent whole mix Chuncheon Dakgalbi including vegetables, while the texture represents the chicken meat.

\section{Statistical analysis}

All data were analyzed using SPSS statistic 19.0 for Windows Evaluation Version (2010). The data were analyzed by one way analysis of variance using Duncan's multiple range tests with examination for significant differences $(p<0.05)$.

\section{Results and Discussion}

\section{Proximate and sensory evaluation}

Table 2 showed the proximate and sensory evaluation of retort pouch packed Chuncheon Dakgalbi which was cooked for different times. There was no significant difference $(p>0.05)$ on water, crude ash, crude protein and fat contents of Chuncheon Dakgalbi cooked for 10, 20 and $30 \mathrm{~min}$.

The panelists scored higher taste of retort pouch packed Chuncheon Dakgalbi which was cooked for 30 min than

Table 2. The proximate analysis and sensory evaluation of home-made retort pouch packed Chuncheon Dakgalbi cooked with different cooking time

\begin{tabular}{cccc}
\hline \hline \multirow{2}{*}{ Parameters } & \multicolumn{3}{c}{ Cooking time (min) } \\
\cline { 2 - 4 } & 10 & \multicolumn{3}{c}{20} \\
\hline Proximate & & & 30 \\
Water & $71.12 \pm 0.51^{\mathrm{a}}$ & $71.32 \pm 0.21^{\mathrm{a}}$ & $71.75 \pm 0.60^{\mathrm{a}}$ \\
Crude ash & $1.21 \pm 0.21^{\mathrm{a}}$ & $1.22 \pm 0.31^{\mathrm{a}}$ & $1.29 \pm 0.44^{\mathrm{a}}$ \\
Crude protein & $24.50 \pm 0.53^{\mathrm{a}}$ & $24.40 \pm 0.33^{\mathrm{a}}$ & $24.25 \pm 0.24^{\mathrm{a}}$ \\
Crude fat & $2.90 \pm 0.23^{\mathrm{a}}$ & $2.91 \pm 0.44^{\mathrm{a}}$ & $2.71 \pm 0.33^{\mathrm{a}}$ \\
\hline Sensory evaluation & & & \\
Color & $6.12 \pm 1.13^{\mathrm{a}}$ & $6.80 \pm 0.60^{\mathrm{a}}$ & $6.81 \pm 0.90^{\mathrm{a}}$ \\
Taste & $6.52 \pm 1.13^{\mathrm{b}}$ & $6.82 \pm 1.05^{\mathrm{ab}}$ & $7.62 \pm 0.62^{\mathrm{a}}$ \\
Texture & $6.11 \pm 0.84^{\mathrm{b}}$ & $6.40 \pm 0.75^{\mathrm{ab}}$ & $6.72 \pm 1.24^{\mathrm{a}}$ \\
Overall & $6.33 \pm 0.60^{\mathrm{b}}$ & $6.80 \pm 0.70^{\mathrm{ab}}$ & $7.00 \pm 1.34^{\mathrm{a}}$ \\
acceptability & & &
\end{tabular}

Data are presented as Means \pm SD.

${ }^{\mathrm{a}-\mathrm{c}}$ Values within each row with different superscripts are significantly different $(p<0.05)$.

${ }^{1)}$ Hedonic scores: $9=$ very good, $7=$ good, $5=$ acceptable, $3=$ poor, and $1=$ very poor. 
that of Dakgalbi which was cooked for $10 \min (p<0.05)$. The similar trends are found on sensory evaluation scores of texture and overall acceptability $(p<0.05)$ in which the higher scores were seen on sample cooked for longer time. The sensory evaluation of texture was objected only the chicken cubes of Dakgalbi. The softer texture of chicken cubes was obtained by prolonging the cooking time from 10 to $30 \mathrm{~min}$. It is known that prolonging the cooking time can reduce the hardness of meat and it means an increase in the sensory value of texture. The relative contribution of the connectives tissue and myofibrillar structures to the shear-force values of meat were altered as cooking temperature and time was increased (Bouton et al., 1981). Ali et al. (2005) reported a lower hardness, cohesiveness, springiness and chewiness of retort pouch packed sardines by increasing the cooking temperature and time. Mohan et al. (2006) reported the less desirable color of shrimp by panelists that was cooked with longer time due to its darker color. Our results showed that no difference was found on the sensory evaluation of color of retort pouch pack of Chuncheon Dakgalbi cooked with different cooking period $(p>0.05)$. The dominant red color of Dakgalbi sauce might be responsible for the color uniformity of packed Dakgalbi even the cooking time was prolonged from 10 to 20 or $30 \mathrm{~min}$.

\section{The pH, TBARS and VBN measurement}

The $\mathrm{pH}$, TBARS and VBN values are presented in Table 3. By prolonging the cooking time from 10 to $30 \mathrm{~min}$, the $\mathrm{pH}$ value of retort pouch packed Chuncheon Dakgalbi on $0 \mathrm{~d}$ of storage was significantly declined from 6.25 to 6.09 $(p<0.05)$. The $\mathrm{pH}$ values of all treatments were declined as the increasing of storage time regardless of the different storage temperature. However, the declined $\mathrm{pH}$ value was tended to be faster in packed Dakgalbi which was cooked for $30 \mathrm{~min}$ than that of 10 and 20 min cooking time treatments. In addition, 30 min cooking time and refrigerator storage maintained the lowest $\mathrm{pH}$ values among treatments during $3 \mathrm{wk}$ of storage.

Prolonging the cooking time from 10 to 30 min significantly promoted the lipid oxidation $(p<0.05)$ from 1.39 to $1.65 \mathrm{mg} \mathrm{MA} / \mathrm{kg}$ sample on $0 \mathrm{~d}$ of storage. The lipid oxidation of retort packed Dakgalbi was increased from 1 to 3 wk of storage both of the packed Dakgalbi stored at $4{ }^{\circ} \mathrm{C}$ and $25^{\circ} \mathrm{C}$. Heating promotes lipid oxidation by disrupting the muscle cell structure and inactivating the antioxidant enzymes (Ahn and Min, 2005). However, the differences of cooking time as well as the storage temperature did not affect the lipid oxidation during storage, except the packed Dakgalbi cooked for $10 \mathrm{~min}$ and stored at $25^{\circ} \mathrm{C}$ at 2 and $3 \mathrm{wk}$. The TBARS value of samples cooked for $10 \mathrm{~min}$ and stored at $25^{\circ} \mathrm{C}$ was higher than that of other treat-

Table 3. Effect of cooking time and storage temperature on the pH, TBARS and VBN of home-made retort pouch packed Chuncheon Dakgalbi

\begin{tabular}{|c|c|c|c|c|c|c|}
\hline \multirow{2}{*}{ Parameter } & \multirow{2}{*}{$\begin{array}{c}\text { Storage } \\
\text { temperature }\end{array}$} & \multirow{2}{*}{$\begin{array}{l}\text { Cooking time } \\
(\mathrm{min})\end{array}$} & \multicolumn{4}{|c|}{ Storage time (wk) } \\
\hline & & & 0 & 1 & 2 & 3 \\
\hline \multirow{6}{*}{$\mathrm{pH}$} & \multirow{3}{*}{$4^{\circ} \mathrm{C}$} & 10 & $6.25 \pm 0.01^{\mathrm{aA}}$ & $6.14 \pm 0.05^{\mathrm{aB}}$ & $6.09 \pm 0.07^{\mathrm{abB}}$ & $6.00 \pm 0.00^{\mathrm{aC}}$ \\
\hline & & 20 & $6.13 \pm 0.01^{\mathrm{bA}}$ & $6.09 \pm 0.03^{\mathrm{abB}}$ & $6.08 \pm 0.01^{\mathrm{abB}}$ & $5.98 \pm 0.04^{\mathrm{aC}}$ \\
\hline & & 30 & $6.09 \pm 0.01^{\mathrm{cA}}$ & $6.05 \pm 0.06^{\mathrm{bAB}}$ & $5.97 \pm 0.01^{\mathrm{bB}}$ & $5.85 \pm 0.11^{\mathrm{bC}}$ \\
\hline & \multirow{3}{*}{$25^{\circ} \mathrm{C}$} & 10 & $6.25 \pm 0.01^{\mathrm{aA}}$ & $6.11 \pm 0.00^{\mathrm{abAB}}$ & $6.15 \pm 0.28^{\mathrm{aAB}}$ & $6.01 \pm 0.10^{\mathrm{aB}}$ \\
\hline & & 20 & $6.13 \pm 0.01^{\mathrm{bA}}$ & $6.07 \pm 0.04^{\mathrm{bA}}$ & $6.00 \pm 0.04^{\mathrm{bB}}$ & $5.99 \pm 0.04^{\mathrm{aB}}$ \\
\hline & & 30 & $6.09 \pm 0.01^{\mathrm{cA}}$ & $6.07 \pm 0.02^{\mathrm{bB}}$ & $6.00 \pm 0.16^{\mathrm{bBC}}$ & $5.96 \pm 0.08^{\mathrm{abC}}$ \\
\hline \multirow{6}{*}{$\begin{array}{c}\text { TBARS } \\
\text { (mg MA/kg } \\
\text { sample) }\end{array}$} & \multirow{3}{*}{$4^{\circ} \mathrm{C}$} & 10 & $1.39 \pm 0.26^{\mathrm{cD}}$ & $1.52 \pm 0.18^{\mathrm{aC}}$ & $2.12 \pm 0.18^{\mathrm{bB}}$ & $2.47 \pm 0.17^{\mathrm{bA}}$ \\
\hline & & 20 & $1.45 \pm 0.05^{\mathrm{bD}}$ & $1.52 \pm 0.07^{\mathrm{aC}}$ & $2.12 \pm 0.24^{\mathrm{bB}}$ & $2.48 \pm 0.10^{\mathrm{bA}}$ \\
\hline & & 30 & $1.65 \pm 0.04^{\mathrm{aC}}$ & $1.68 \pm 0.43^{\mathrm{aC}}$ & $2.14 \pm 0.13^{\mathrm{bB}}$ & $2.54 \pm 0.21^{\mathrm{bA}}$ \\
\hline & \multirow{3}{*}{$25^{\circ} \mathrm{C}$} & 10 & $1.39 \pm 0.26^{\mathrm{cD}}$ & $1.75 \pm 0.44^{\mathrm{aC}}$ & $2.42 \pm 0.25^{\mathrm{aB}}$ & $3.64 \pm 0.22^{\mathrm{aA}}$ \\
\hline & & 20 & $1.45 \pm 0.05^{\mathrm{bD}}$ & $1.75 \pm 0.06^{\mathrm{aC}}$ & $2.28 \pm 0.16^{\mathrm{abB}}$ & $2.61 \pm 0.17^{\mathrm{bA}}$ \\
\hline & & 30 & $1.65 \pm 0.04^{\mathrm{aC}}$ & $1.65 \pm 0.12^{\mathrm{aC}}$ & $2.11 \pm 0.21^{\mathrm{bB}}$ & $2.59 \pm 0.14^{\mathrm{bA}}$ \\
\hline \multirow{6}{*}{ VBN (mg\%) } & \multirow{3}{*}{$4^{\circ} \mathrm{C}$} & 10 & $9.69 \pm 0.26^{\mathrm{aB}}$ & $9.67 \pm 1.84^{\mathrm{bB}}$ & $11.95 \pm 0.50^{\mathrm{abA}}$ & $11.99 \pm 1.01^{\mathrm{cA}}$ \\
\hline & & 20 & $9.80 \pm 0.35^{\mathrm{aB}}$ & $10.34 \pm 1.01^{\mathrm{bAB}}$ & $11.73 \pm 1.03^{\mathrm{bA}}$ & $11.78 \pm 1.16^{\mathrm{cA}}$ \\
\hline & & 30 & $9.62 \pm 0.14^{\mathrm{aC}}$ & $11.43 \pm 0.85^{\mathrm{abB}}$ & $12.22 \pm 0.20^{\mathrm{aA}}$ & $12.29 \pm 0.60^{\mathrm{bcA}}$ \\
\hline & \multirow{3}{*}{$25^{\circ} \mathrm{C}$} & 10 & $9.69 \pm 0.26^{\mathrm{aC}}$ & $11.71 \pm 0.91^{\mathrm{abBC}}$ & $12.58 \pm 0.84^{\mathrm{aB}}$ & $14.18 \pm 2.71^{\mathrm{aA}}$ \\
\hline & & 20 & $9.80 \pm 0.35^{\mathrm{aB}}$ & $11.29 \pm 1.75^{\mathrm{abAB}}$ & $12.03 \pm 1.32^{\mathrm{abA}}$ & $12.54 \pm 1.01^{\mathrm{bcA}}$ \\
\hline & & 30 & $9.62 \pm 0.14^{\mathrm{aC}}$ & $12.47 \pm 0.91^{\mathrm{aB}}$ & $12.55 \pm 0.73^{\mathrm{abB}}$ & $13.28 \pm 1.30^{\mathrm{abA}}$ \\
\hline
\end{tabular}

Data are presented as Means \pm SD.

${ }^{\text {a-d }}$ Values within each column with different superscripts are significantly different $(p<0.05)$.

${ }^{\text {A-D }}$ Values within each row with different superscripts are significantly different $(p<0.05)$. 
ments after 2 wks of storage.

The protein deterioration represented by VBN value of retort pouch packed Chuncheon Dakgalbi was not significantly affected by the cooking time and storage temperature $(p>0.05)$. However, the packed Dakgalbi which was cooked with longer time tended to have a higher VBN value compared to the packed Dakgalbi with shorter cooking period. This increase could be due to the breakdown of proteins, amino acids, and other nitrogenous compounds (Chia et al., 1983). The longer cooking time promotes the protein breakdown resulted a higher VBN value. Also, higher storage temperature tended to promote protein deterioration of the packed Dakgalbi during 3 wks storage. High cooking temperature enhanced protein oxidation in meat products (Ganhao et al., 2010). It was also well known that heat treatment accelerated lipid oxidation in muscle food. Heating degrades myoglobin that altered the release of iron which increases its pro-oxidant potential in cooked meats (Kristensen and Purslow, 2001).

\section{Instrumental color}

The instrument color values such as CIE L* (lightness), CIE $\mathrm{a}^{*}$ (redness), and CIE $\mathrm{b}^{*}$ (yellowness) are presented in Table 4. The lightness of retort pouch packed Chuncheon Dakgalbi on $0 \mathrm{~d}$ of storage tended to be declined $(p<0.05)$ by prolonging the cooking time from 10 to 30 min (from 48.7 to 47.6 ), but no effect of prolonging the cooking time by $20 \mathrm{~min}$ was found $(p>0.05)$. The lower lightness value showed the darker color of sample. Mohan et al. (2006) reported the darker color of shrimp kuruma in cans which was cooked for longer time. During $3 \mathrm{wks}$ storage, the lightness of packed Dakgalbi which was stored on a refrigerator remained stable while the other packed Dakgalbi stored on room temperature was increased on 1 and $2 \mathrm{wk}$ then again declined on $3 \mathrm{wk}$ of storage. Storage condition significantly affected on lightness of the packed Dakgalbi $(p<0.05)$, in which $25^{\circ} \mathrm{C}$ storage temperature increased the lightness on 1 and $2 \mathrm{wk}$ and those were higher than that of $4^{\circ} \mathrm{C}$ storage temperature.

The effect of both cooking time and storage temperature on redness value of retort pouch packed Chuncheon Dakgalbi was not clear. The ingredients of the packed Dakgalbi such as Korean pepper paste (gochujang) and dried hot pepper powder, which originally were red color, were responsible of the massive red color of the packed Dakgalbi. However, some minor changes were observed during 3 wks storage. For instance, the redness of the packed Dakgalbi tended to decline by prolonging the cooking time. These lower redness values were last for $3 \mathrm{wks}$ storage at $4^{\circ} \mathrm{C}$ and $25^{\circ} \mathrm{C}$. Moreover, the packed Dakgalbi stored at $4^{\circ} \mathrm{C}$ had a slightly higher redness value than that of its counterpart.

Table 4. Effect of cooking time and storage temperature on the instrumental color of home-made retort pouch packed Chuncheon Dakgalbi

\begin{tabular}{|c|c|c|c|c|c|c|}
\hline \multirow{2}{*}{ Parameter } & \multirow{2}{*}{$\begin{array}{c}\text { Storage } \\
\text { temperature }\end{array}$} & \multirow{2}{*}{$\begin{array}{l}\text { Cooking time } \\
(\mathrm{min})\end{array}$} & \multicolumn{4}{|c|}{ Storage time (wk) } \\
\hline & & & 0 & 1 & 2 & 3 \\
\hline \multirow{6}{*}{ CIE L* } & \multirow{3}{*}{$4^{\circ} \mathrm{C}$} & 10 & $48.74 \pm 1.50^{\mathrm{aA}}$ & $48.02 \pm 0.62^{\mathrm{bcA}}$ & $48.32 \pm 0.61^{\mathrm{bcA}}$ & $48.22 \pm 1.12^{\mathrm{a} A}$ \\
\hline & & 20 & $48.13 \pm 1.22^{\mathrm{aA}}$ & $48.23 \pm 0.82^{\mathrm{bcA}}$ & $48.61 \pm 1.10^{\mathrm{bcA}}$ & $48.02 \pm 0.81^{\mathrm{abA}}$ \\
\hline & & 30 & $47.63 \pm 0.80^{\mathrm{aA}}$ & $47.33 \pm 0.83^{\mathrm{cA}}$ & $48.11 \pm 1.20^{\mathrm{cA}}$ & $47.43 \pm 1.75^{\mathrm{abA}}$ \\
\hline & \multirow{3}{*}{$25^{\circ} \mathrm{C}$} & 10 & $48.70 \pm 1.50^{\mathrm{aAB}}$ & $50.02 \pm 5.60^{\mathrm{a} A}$ & $49.70 \pm 1.00^{\mathrm{a} A}$ & $48.02 \pm 0.93^{\mathrm{abB}}$ \\
\hline & & 20 & $48.11 \pm 1.23^{\mathrm{aAB}}$ & $49.91 \pm 1.41^{\mathrm{aA}}$ & $49.04 \pm 0.84^{\mathrm{abA}}$ & $47.02 \pm 1.72^{\mathrm{bcB}}$ \\
\hline & & 30 & $47.61 \pm 0.84^{\mathrm{aB}}$ & $49.71 \pm 6.60^{\mathrm{aA}}$ & $49.23 \pm 1.74^{\mathrm{aA}}$ & $46.34 \pm 2.32^{\mathrm{cB}}$ \\
\hline \multirow{6}{*}{ CIE a* } & \multirow{3}{*}{$4^{\circ} \mathrm{C}$} & 10 & $17.42 \pm 0.91^{\mathrm{aB}}$ & $17.51 \pm 0.81^{\mathrm{aC}}$ & $18.62 \pm 0.64^{\mathrm{aB}}$ & $19.30 \pm 0.80^{\mathrm{a} A}$ \\
\hline & & 20 & $17.21 \pm 0.82^{\mathrm{aB}}$ & $17.31 \pm 0.61^{\mathrm{abB}}$ & $18.12 \pm 0.53^{\mathrm{bAB}}$ & $18.82 \pm 0.51^{\mathrm{bA}}$ \\
\hline & & 30 & $17.11 \pm 0.72^{\mathrm{aB}}$ & $17.22 \pm 0.52^{\mathrm{abB}}$ & $17.70 \pm 0.32^{\mathrm{bA}}$ & $17.84 \pm 0.91^{\mathrm{cdA}}$ \\
\hline & \multirow{3}{*}{$25^{\circ} \mathrm{C}$} & 10 & $17.40 \pm 0.90^{\mathrm{aB}}$ & $17.62 \pm 0.63^{\mathrm{aB}}$ & $18.10 \pm 0.72^{\mathrm{bA}}$ & $18.34 \pm 0.52^{\mathrm{cA}}$ \\
\hline & & 20 & $17.20 \pm 0.82^{\mathrm{aB}}$ & $16.10 \pm 3.13^{\mathrm{bcC}}$ & $18.04 \pm 1.02^{\mathrm{bA}}$ & $17.92 \pm 0.71^{\mathrm{cdA}}$ \\
\hline & & 30 & $17.14 \pm 0.73^{\mathrm{aA}}$ & $15.23 \pm 3.40^{\mathrm{cB}}$ & $17.84 \pm 0.80^{\mathrm{bA}}$ & $17.52 \pm 0.73^{\mathrm{dA}}$ \\
\hline \multirow{6}{*}{ CIE b* } & \multirow{3}{*}{$4^{\circ} \mathrm{C}$} & 10 & $31.30 \pm 1.60^{\mathrm{aB}}$ & $30.40 \pm 1.10^{\mathrm{aC}}$ & $31.93 \pm 1.40^{\mathrm{aB}}$ & $33.50 \pm 1.74^{\mathrm{aA}}$ \\
\hline & & 20 & $31.10 \pm 1.42^{\mathrm{aA}}$ & $30.31 \pm 1.41^{\mathrm{aB}}$ & $32.22 \pm 1.32^{\mathrm{aA}}$ & $32.02 \pm 1.14^{\mathrm{bA}}$ \\
\hline & & 30 & $31.12 \pm 1.72^{\mathrm{aA}}$ & $29.22 \pm 0.81^{\mathrm{aB}}$ & $32.23 \pm 1.22^{\mathrm{aA}}$ & $31.72 \pm 1.74^{\mathrm{bcA}}$ \\
\hline & \multirow{3}{*}{$25^{\circ} \mathrm{C}$} & 10 & $31.33 \pm 1.64^{\mathrm{aB}}$ & $30.73 \pm 1.40^{\mathrm{aB}}$ & $32.64 \pm 1.42^{\mathrm{a} A}$ & $31.61 \pm 1.02^{\mathrm{bcB}}$ \\
\hline & & 20 & $31.10 \pm 1.44^{\mathrm{aA}}$ & $30.21 \pm 9.11^{\mathrm{aB}}$ & $32.60 \pm 1.54^{\mathrm{aA}}$ & $30.50 \pm 1.82^{\mathrm{cB}}$ \\
\hline & & 30 & $31.12 \pm 1.71^{\mathrm{aA}}$ & $30.00 \pm 9.21^{\mathrm{aB}}$ & $31.70 \pm 1.43^{\mathrm{aA}}$ & $29.01 \pm 2.70^{\mathrm{dAB}}$ \\
\hline
\end{tabular}

Data are presented as Means \pm SD. $(n=3)$.

${ }^{\mathrm{a}-\mathrm{d}}$ Values within each column with different superscripts are significantly different $(p<0.05)$.

${ }^{\text {A-D }}$ Values within each row with different superscripts are significantly different $(p<0.05)$. 
Table 5. Effect of cooking time and storage temperature on total aerobic and anaerobic bacteria counts of home-made retort pouch packed Chuncheon Dakgalbi

\begin{tabular}{|c|c|c|c|c|c|c|c|}
\hline \multirow{2}{*}{ Parameter } & \multirow{2}{*}{$\begin{array}{c}\text { Storage } \\
\text { temperature }\end{array}$} & \multirow{2}{*}{$\begin{array}{l}\text { Cooking time } \\
\text { (min) }\end{array}$} & \multicolumn{5}{|c|}{ Storage time (wk) } \\
\hline & & & 0 & 1 & 2 & 3 & 4 \\
\hline \multirow{6}{*}{$\begin{array}{c}\text { Total } \\
\text { Aerobic } \\
\text { Bacteria }\end{array}$} & \multirow{3}{*}{$4^{\circ} \mathrm{C}$} & 10 & $\mathrm{ND}^{*}$ & ND & ND & ND & ND \\
\hline & & 20 & ND & ND & ND & ND & ND \\
\hline & & 30 & ND & ND & ND & ND & ND \\
\hline & \multirow{3}{*}{$25^{\circ} \mathrm{C}$} & 10 & ND & ND & ND & $4.72 \pm 0.84^{\mathrm{B}}$ & $6.40 \pm 1.24^{\mathrm{A}}$ \\
\hline & & 20 & ND & ND & ND & ND & ND \\
\hline & & 30 & ND & ND & ND & ND & ND \\
\hline \multirow{6}{*}{$\begin{array}{c}\text { Total } \\
\text { Anaerobic } \\
\text { Bacteria }\end{array}$} & \multirow{3}{*}{$4^{\circ} \mathrm{C}$} & 10 & ND & ND & ND & ND & ND \\
\hline & & 20 & ND & ND & ND & ND & ND \\
\hline & & 30 & ND & ND & ND & ND & ND \\
\hline & \multirow{3}{*}{$25^{\circ} \mathrm{C}$} & 10 & ND & ND & ND & $5.42 \pm 1.71^{\mathrm{B}}$ & $7.71 \pm 0.90^{A}$ \\
\hline & & 20 & ND & ND & ND & ND & ND \\
\hline & & 30 & ND & ND & ND & ND & ND \\
\hline
\end{tabular}

Data are presented as Means \pm SD. $(n=6)$.

${ }^{\mathrm{A}-\mathrm{B}}$ Values within each row with different superscripts are significantly different $(p<0.05)$.

${ }^{*} \mathrm{ND}=$ Not Detected $(0 \mathrm{CFU} / \mathrm{g}$ sample).

There was no effect of cooking time and storage temperature on yellowness of retort pouch packed Chuncheon Dakgalbi during 3 wks of storage. A slight difference was only found on the last week of storage in which the yellowness was declined by prolonging the cooking time $(p<$ 0.05 ) and it seemed that the storage conditions at $4^{\circ} \mathrm{C}$ maintained the yellowness of the packed Dakgalbi until the end of storage period, while the storage conditions at $25^{\circ} \mathrm{C}$ could not maintain yellowness which was declined at the end of storage.

\section{Total aerobic and anaerobic bacteria}

Table 5 shows the total aerobic and anaerobic bacteria counts of retort pouch packed Chuncheon Dakgalbi. The autoclaving of retort pouch packed Chuncheon Dakgalbi at $110^{\circ} \mathrm{C}$ with pressure $0.75 \mathrm{Kgf} / \mathrm{cm}^{2}$ for 10,20 and 30 min killed both aerobic and anaerobic bacteria. By storing at $4^{\circ} \mathrm{C}$, the aerobic and anaerobic bacteria were not-detected on all cooking time during $4 \mathrm{wk}$ storage. Similarly, the aerobic and anaerobic bacteria counts of the packed Dakgalbi were not detected in the sample during room temperature storage for $4 \mathrm{wk}$, with the exception of the packed Dakgalbi cooked for $10 \mathrm{~min}$ on 3 and $4 \mathrm{wk}$. On $3 \mathrm{wk}$ of storage, the aerobic bacteria of the packed Dakgalbi cooked for $10 \mathrm{~min}$ started to grow at level 4.7 Log CFU/g and the anaerobic bacteria at 5.4 Log CFU/g. Afterwards, the aerobic and anaerobic bacteria counts reached out 6.4 and 7.7 Log CFU/g sample respectively. From those data, it was noted that autoclaving duration by $10 \mathrm{~min}$ was enough to eliminate bacteria but not their spores. These spores seemed to be dormant and will grow at the room temperature. Steele and Wright (2001) mentioned that with improper cooling through the critical range of 12.8 and $48.9^{\circ} \mathrm{C}$, the potential for spore germination, outgrowth, and toxin production is indeed a concern. The spores that might be contained in the packed Dakgalbi remained in dormant when it stored on $4^{\circ} \mathrm{C}$. However, $20 \mathrm{~min}$ of cooking time are required to eliminate bacteria when retort packed Chuncheon Dakgalbi are supposed to be stored for 1 mon at room temperature.

\section{Conclusion}

In this study, retort pouch packed Chuncheon Dakgalbi which was cooked at $110^{\circ} \mathrm{C}$ with pressure $0.75 \mathrm{Kgf} / \mathrm{cm}^{2}$ for $30 \mathrm{~min}$ had higher sensory scores of taste and texture. However, prolonging the cooking time from 10 to $30 \mathrm{~min}$ promoted lipid oxidation and tended to improved protein deterioration. A darker color (lower CIE L* value) was found on Chuncheon Dakgalbi which was cooked for longer time. The water, crude ash, crude protein and crude fat were not affected by cooking time. The cooking for 10, 20 and 30 min eliminated both aerobic and anaerobic bacteria. Storage condition significantly affected lightness of the packed Dakgalbi, in which $25^{\circ} \mathrm{C}$ storage temperature increased the lightness on 1 and $2 \mathrm{wk}$ and those were higher than that of $4^{\circ} \mathrm{C}$ storage temperature. Storing at $25^{\circ} \mathrm{C}$ slightly promoted lipid oxidation at the end of storage but did not affected protein deterioration. On microbial analysis, the aerobic and anaerobic bacteria were notdetected from all cooking time during $4 \mathrm{wk}$ storage at $4^{\circ} \mathrm{C}$, but those bacteria were detected started on $3 \mathrm{wk}$ of storage in Chuncheon Dakgalbi stored at $25^{\circ} \mathrm{C}$. 


\section{Acknowledgements}

This research was supported by The Research Center for Export for Poultry Products (Project number 908001-051-SB350), Ministry for Food, Agriculture, Forestry and Fisheries, Republic of Korea.

\section{References}

1. Ahn, D. U. and Min, B. (2005) Mechanism of lipid peroxidation in meat and meat products-A review. Food Sci. Biotechnol. 14, 152-163.

2. Ali, A., Sudhir, B., and Gopal, T. K. S. (2005) Effect of heat processing on the texture profile of canned and retort pouch packed oil sardine (Sardinella longiceps) in oil medium. $J$. Food Sci. 70, 350-354.

3. Ali, A. A., Sudhir, B., and Gopal, T. K. S. (2006) Effect of rotation on the heat penetration characteristics of thermally processed tuna in oil in retort pouches. Int. J. Food. Sci. Technol. 41, 215-219.

4. AOAC (2000) Official Methods of Analysis. 17th ed, Association of Official Analytical Chemists, Washington, DC, pp. 759.

5. Awuah, G. B., Ramaswamy, H. S., and Economides, A. (2007) Thermal processing and quality: Principles and overview. Chem. Eng. Process 46, 584-602.

6. Bouton, P. E., Harris, P. V., and Ratcliff, D. (1981) Effect of cooking temperature and time on the shear properties of meat. J. Food Sci. 46, 1082-1087.

7. Byun, Y. J. and Whiteside, W. S. (2007) The effect of barrier materials on salmon quality and retort pouch properties stored under accelerated storage conditions. Abstract, IFT annual meeting, Orlando, USA.

8. Chia, S. S., Baker, R. C., and Hotchkiss, J. H. (1983) Quality comparison of thermo processed fishery products in cans and retortable pouches. J. Food Sci. 48, 1521-1525.

9. Cremer, M. L. and Pizzimenti, K. V. (1992) Effects of packaging, equipment, and storage time on energy used for rehea- ting beef stew. J. Am. Diet Assoc. 92, 954-958.

10. Ganhao, R., Morcuende, D., and Estevez, M. (2010) Protein oxidation in emulsified cooked burger patties with added fruit extracts: Influence on color and texture deterioration during chill storage. Meat Sci. 85, 402-409.

11. Griffin, R. C. (1987) Retortable plastic packaging. In: Modern processing, packaging and distribution systems for food. Paine, F. A. (ed) Blackie and Son Ltd., London, pp. 1-19.

12. Heidelbaugh, N. D. and Karel, M. (1970) Changes in pouched heat-processed foods. Modern Packaging 43, 80-90.

13. Jang, D. H. and Lee, K. T. (2012) Quality changes of readyto-eat ginseng chicken porridge during storage at $25^{\circ} \mathrm{C}$. Meat Sci. 92, 469-473.

14. Kohsaka, K. (1975) Freshness preservation of food and measurement. Food Ind. 18, 105-111.

15. Kristensen, L. and Purslow, P. P. (2001) The effect of processing temperature and addition of mono-and di-valent salts on the heme-nonheme-iron ration in meat. Food Chem. 73, 433-439.

16. Lyon, B. G. and Klose, A. A. (1981) Effect of heat processing in cans and retort pouches on sensory properties of fowl meat. J. Food Sci. 46, 227-233.

17. Mohan, C. O., Ravishankar, C. N., Bindu, J., Geethalakshmi, V., and Gopal, T. K. S. (2006) Effect of thermal process time on quality of "shrimp kuruma" in retortable pouches and aluminum cans. J. Food Sci. 71, S496-S500.

18. Sinnhuber, R. O. and Yu, T. C. (1977) The 2-thiobarbituric acid reaction, an objective measu-re of the oxidative deterioration occurring in fats and oils. J. Jpn. Soc. Fish Sci. 26, 259-267.

19. SPSS. (2010). Statistical package for social sciences for Windows (version 19.0). Chicago, IL: SPSS Inc.

20. Steele, F. M. and Wright, K. H. (2001) Cooling rate effect on outgrowth of Clostridium perfringens in cooked, ready-to-eat turkey breast roasts. Poultry Sci. 80, 813-816.

21. Trevino, J. A. (2009) Effect of oscillating and static retort thermal processing technology using an institutional size pouch. Master thesis, Clemson Univ., South Carolina, USA.

(Received 2013.8.29/Revised 2013.11.20/Accepted 2013.11.21) 